\title{
Molecular analysis of the diversity of vaginal microbiota associated with bacterial vaginosis
}

\author{
Zongxin Ling ${ }^{1}$, Jianming Kong ${ }^{1,2}$, Fang Liu', Haibin Zhu ${ }^{3}$, Xiaoyi Chen ${ }^{1}$, Yuezhu Wang ${ }^{4}$, Lanjuan Li ${ }^{1}$, \\ Karen E Nelson ${ }^{5}$, Yaxian Xia ${ }^{3^{*}}$, Charlie Xiang ${ }^{1,5^{*}}$
}

\begin{abstract}
Background: Bacterial vaginosis (BV) is an ecological disorder of the vaginal microbiota that affects millions of women annually, and is associated with numerous adverse health outcomes including pre-term birth and the acquisition of sexually transmitted infections. However, little is known about the overall structure and composition of vaginal microbial communities; most of the earlier studies focused on predominant vaginal bacteria in the process of BV. In the present study, the diversity and richness of vaginal microbiota in 50 BV positive and 50 healthy women from China were investigated using culture-independent PCR-denaturing gradient gel electrophoresis (DGGE) and barcoded 454 pyrosequencing methods, and validated by quantitative PCR.
\end{abstract}

Results: Our data demonstrated that there was a profound shift in the absolute and relative abundances of bacterial species present in the vagina when comparing populations associated with healthy and diseased conditions. In spite of significant interpersonal variations, the diversity of vaginal microbiota in the two groups could be clearly divided into two clusters. A total of 246,359 high quality pyrosequencing reads was obtained for evaluating bacterial diversity and 24,298 unique sequences represented all phylotypes. The most predominant phyla of bacteria identified in the vagina belonged to Firmicutes, Bacteroidetes, Actinobacteria and Fusobacteria. The higher number of phylotypes in BV positive women over healthy is consistent with the results of previous studies and a large number of low-abundance taxa which were missed in previous studies were revealed. Although no single bacterium could be identified as a specific marker for healthy over diseased conditions, three phyla - Bacteroidetes, Actinobacteria and Fusobacteria, and eight genera including Gardnerella, Atopobium, Megasphaera, Eggerthella, Aerococcus, Leptotrichia/Sneathia, Prevotella and Papillibacter were strongly associated with BV $(p<0.05)$. These genera are potentially excellent markers and could be used as targets for clinical BV diagnosis by molecular approaches.

Conclusions: The data presented here have clearly profiled the overall structure of vaginal communities and clearly demonstrated that BV is associated with a dramatic increase in the taxonomic richness and diversity of vaginal microbiota. The study also provides the most comprehensive picture of the vaginal community structure and the bacterial ecosystem, and significantly contributes to the current understanding of the etiology of BV.

\section{Background}

An enormous number of microorganisms, the vast majority of which are bacterial species, are known to colonize and form complex communities, or microbiota, at various sites within and on the human body [1,2]. Microbial cells that thrive on and within the human

\footnotetext{
* Correspondence: xya55@sohu.com; cxiang@zju.edu.cn

${ }^{1}$ State Key Laboratory for Diagnosis and Treatment of Infectious Diseases, the First Affiliated Hospital, College of Medicine, Zhejiang University, Hangzhou, Zhejiang, 310003, China

${ }^{3}$ Department of Obstetrics and Gynecology, the First Affiliated Hospital,

College of Medicine, Zhejiang University, Hangzhou, Zhejiang, 310003, China

Full list of author information is available at the end of the article
}

body are approximately 10 times more numerous than our own cells and contain, in aggregate, about 100 times more genes, leading to the suggestion that humans and our microbial symbionts be considered "supraorganisms" [3]. A growing body of evidence suggests that the composition and function of the microbiota in different human body habitats plays a vital role in human development, physiology, immunity, and nutrition [1,4-8]. As one of the important human- microbial habitats, the vagina harbors different species of bacteria in very large numbers that are known to have important effects on health [9]. Many of these bacteria such as hydrogen

\section{Biomed Central}


peroxide- and lactic acid- producing Lactobacillus spp. are not simply passive or transient colonizers, but rather appear to be adapted to the specific environment of the vagina [10-12]. These resident species effectively constitute an ecological guild - a group of species that have similar requirements and play a similar role within a community - and maintaining high numbers of these populations is a hallmark of healthy conditions [13]. The dramatic changes in the types and relative proportions of the microbial species in the vagina could lead to a diseased state [14]. One important component of the Human Microbiome Project (HMP), states that it is necessary to explore the bacterial diversity of vagina in health and disease and to understand whether changes in the vaginal microbiome can be correlated with changes in human health [2].

$\mathrm{BV}$ is the most prevalent lower genital tract infection in women of reproductive age throughout the world [15-18]. It affects millions of women annually [19] and is strongly associated with several adverse health outcomes, including preterm labor and delivery [20,21], pelvic inflammatory disease [22], postpartum and postabortal endometritis [23], and increased susceptibility to infection with various pathogens, such as Neisseria gonorhoeae, Trichomonas vaginalis, Chlamydia trachomatis, Candida, and even HPV, HSV-2, and HIV-1 [24-30]. Abnormal vaginal discharge may be the only symptom of BV, and many affected women are asymptomatic [31]. Zhou et al. have suggested that a certain number of women without any symptoms do have vaginal communities that resemble BV [13]. Previous studies have demonstrated that $\mathrm{BV}$ is a polymicrobial syndrome, characterized by a shift in vaginal microbiota from a predominant population of Lactobacillus spp. [14,32] to their gradual or total replacement with anaerobes such as Gardnerella vaginalis [33], Morbiluncus spp. [34], Prevotella spp. [14], Mycoplasma hominis [21] and the recently identified metronidazole resistant Atopobium vaginae [35]. These species are however also found in subjects who do not suffer from BV with low copy numbers and thus cannot be used as a specific marker for disease.

Because of our inability to cultivate most of the microbial species that reside in the vagina, we have not fully understood the taxonomic composition of the vaginal microbiota, its community structure, and ultimately, its function. With the advent of new molecular techniques, we have been able to investigate bacterial diversity in different microhabitats using molecular fingerprinting methods and sequence analysis of microbial small subunit ribosomal (r) RNA genes (16S rRNA) and other universal targets (such as cpn60) [13,36,37]. Among these molecular fingerprinting methods, PCR-DGGE represents a rapid and reliable technique to identify the predominant microbiota in various ecological niches $[38,39]$. Sequencing of $16 \mathrm{~S}$ rRNA genes from different samples by constructing clone libraries, (typically at most a few thousand clones from a low number of individuals), has revolutionized our understanding of microbial systematics and diversity $[40,41]$. However, this cloning and sequencing method identifies only the predominant microorganisms in a sample. Detection of low-abundance taxa requires analysis of datasets that are orders of magnitude larger than those currently available [42]. The recently available high-throughput 454 pyrosequencing now allows for very in-depth sequencing and analysis of microbial community composition, and also allow for a dramatic increase in throughput via parallel in-depth analysis of a large number of samples with limited sample processing and lower costs [43-45].This technique has been successfully used in various ecosystems including deep mines [46], soil [47], fermented seafood [48], skin [49], chronic wounds [50], and oral microbiota [42].

In order to better estimate the diversity of the vaginal community of the healthy and BV positive women, and to identify the key population changes relevant to BV development, we first utilized PCR-DGGE with broad range primers that correspond to the bacterial $16 \mathrm{~S}$ rRNA hypervariable V3 region to investigate the predominant vaginal microbiota in these populations. We then used massively parallel pyrosequencing, combined with a DNA barcoding, to characterize the overall structure and composition of the vaginal bacterial community in $50 \mathrm{BV}$ and $50 \mathrm{CN}$ (non-infected healthy women; $\mathrm{CN}$ ) individuals in China. We also quantified the abundance of total Bacteria and bacterial subgroups that associated significantly with BV using quantitative PCR (qPCR). Our data provides a more comprehensive picture over current knowledge of the community structure of the vaginal bacterial ecosystem. These results also help to define the potential pathogenic populations in $\mathrm{BV}$ and provide new insights into the etiology and treatment of the disease.

\section{Results}

PCR-DGGE analysis of vaginal bacterial communities

PCR-DGGE is a useful tool to examine microbial diversity and community structure in specific microhabitats and has been widely applied for comparative analysis of parallel samples. The differences of DGGE profiles in the same community DNA samples might be caused by different primer sets selected targeting the different hypervariable regions of the $16 \mathrm{~S}$ rRNA genes. The hypervariable region(s) chosen for amplification can influence the PCR-DGGE profiles and diversity indices produced from community DNA samples, and even subtle differences in primer sequences can result in 
substantially different profiles and downstream assessments of microbial diversity. By comparing different hypervariable regions of $16 \mathrm{~S}$ rRNA genes for PCRDGGE, Yu and Morrison (2004) have shown that the DGGE profiles of the V3 region were the most reliable [51]. As shown in Figure $1 \mathrm{~A}$, the PCR-DGGE profiles of $\mathrm{BV}$ and $\mathrm{CN}$ revealed significant differences in the overall structure and composition of the vaginal community by targeting the V3 region of $16 \mathrm{~S}$ rDNA. Bacterial diversity was higher in the BV group than that in the $\mathrm{CN}$ group. DGGE profiles were significantly different from one another and varied with the participants. Figure $1 \mathrm{~B}$ depicts the results of Ward's analysis in which the Dice coefficient for measuring similarity in banding patterns was applied. The BV and $\mathrm{CN}$ groups displayed a statistically significant clustering of profiles, cluster I (BV group) and cluster II (CN group). 11 dominant fragments that could represent the pattern of the DGGE profiles were excised from the DGGE lanes, reamplified, sequenced and identified by BLAST with the $16 \mathrm{~S}$ rRNA V3 region sequences. Lactobacillus was the predominant genus in the $\mathrm{CN}$ group and bacterial diversity of the $\mathrm{BV}$ group was far more complex and was dominated by $A$. vaginae, uncultured Sneathia sp., Fusobacterium nucleatum subsp., uncultured Eggerthella sp., uncultured Megasphaera sp., Clostridium acetobutylicum and Clostridium thermocellum. From these results, we propose that PCR-DGGE analysis could be used to monitor the dramatic shift of bacterial transition and routinely defined BV in laboratory.

\section{Sequence analysis by pyrosequencing}

From $50 \mathrm{BV}$ and $50 \mathrm{CN}$ individuals, more than 321,400 PCR amplicons of the V3 hyper-variable regions of the $16 \mathrm{~S}$ rRNA gene were sequenced, of which a total of 246,359 pyrosequencing tags passed quality control, and were included in our data analysis. Specifically, we obtained 90,227 sequences from the BV group and 156,132 sequences from the $\mathrm{CN}$ group respectively. The average length of the sequences was $145 \mathrm{bp}$ after trimming the primers and the average number of sequence reads was 2,464 per sample. The total number of unique sequences from the two groups was 24,298 and represented all phylotypes. It was unexpected that we obtained more sequences from $\mathrm{CN}$ samples than from BV samples $(p<0.05$, data not shown) because the same amount of bacterial DNA was used for preparing the library for pyrosequencing. It can be assumed that the biased ratio of the two groups was not only because of an inefficiency in the emPCR technique for different species of vaginal bacteria, but also because of the impurities or unknown compounds disturbing the accurate measurement of DNA amount $[48,52]$.

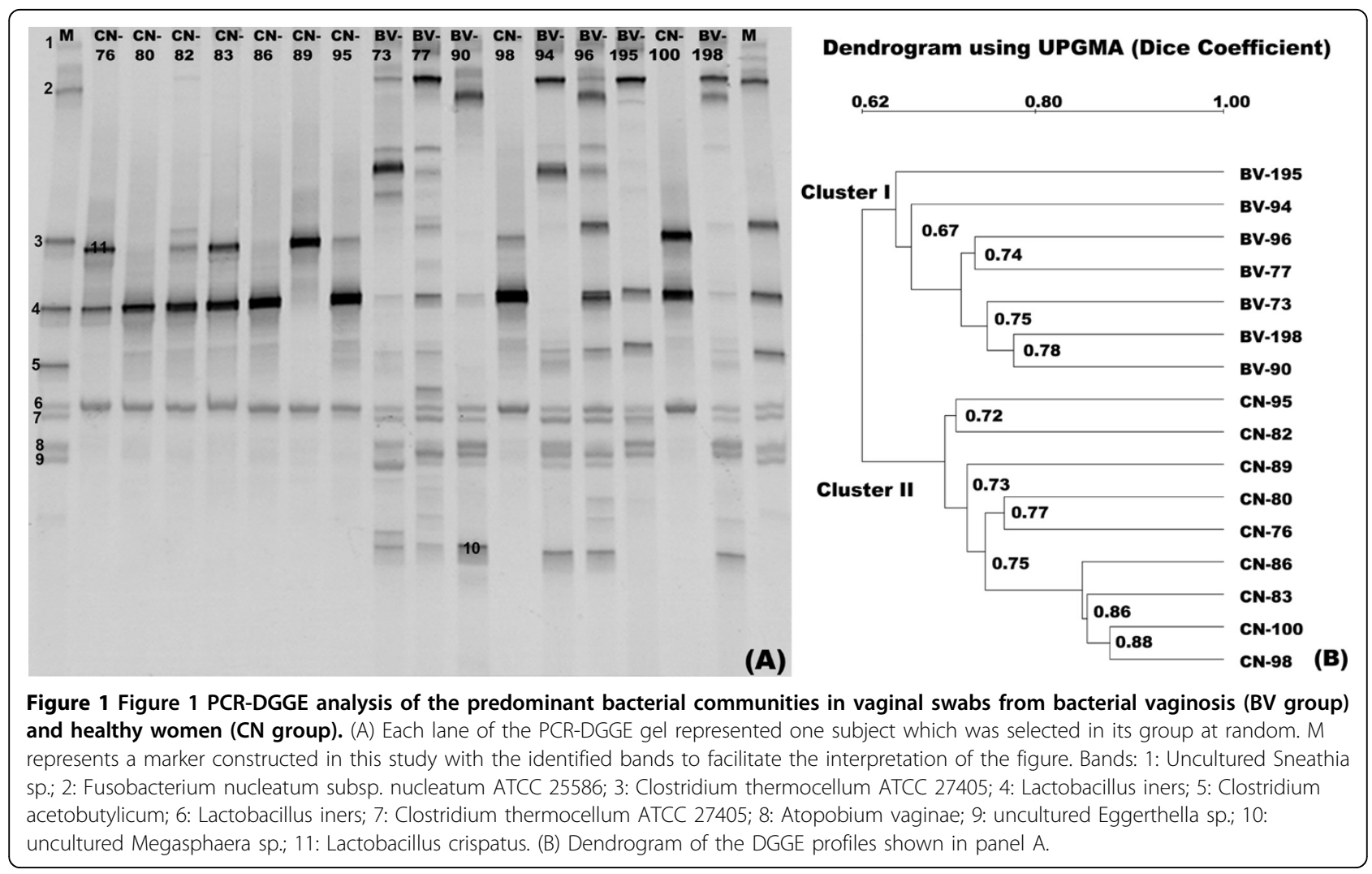


The diversity of vaginal microbiota in BV and $\mathrm{CN}$ individuals

The numbers of species detected in a sample, or the numbers of organisms discerned at any given phylogenetic level, are strongly affected by the number of sequences analyzed. Rarefaction analysis provides a powerful method for evaluating the diversity and richness of different microhabitats in the human body. Rarefaction curves were generated for unique, $1 \%, 2 \%, 3 \%$, $5 \%$ and $10 \%$ sequence dissimilarities as described previously [47]. As shown in Figure 2, we found that there was much more richness in bacterial diversity in BV individuals than in $\mathrm{CN}$ individuals at the $3 \%$ dissimilarity level. The number of OTUs continued to increase at the $3 \%$ or $5 \%$ dissimilarity level in the BV group, however, the rarefaction curve in the $\mathrm{CN}$ group almost reached the saturation level, which indicated that additional sampling was needed to determine the true microbial diversity in the BV vaginal community. Based upon the literature, the nonparametric ACE and Chao1 estimators are correlated positively with the number of sequences analyzed [53] and overestimate the number of species while the rarefaction estimator underestimates the number of species at the $0 \%$ dissimilarity level. However, the rarefaction estimator could accurately predict the number of species at the $3 \%$ dissimilarity level and the number of genera at the 5\% dissimilarity level.
For the two groups of vaginal communities analyzed at the 3\% dissimilarity level, the number of OTUs detected was close to the total number of OTUs estimated by Chaol and ACE diversity indices, presenting additional evidence that the natural communities were well covered during sequencing (Table 1). Good's coverage was more than $99.0 \%$ for all sequences in the two groups, indicating that less than one additional phylotype would be expected for every 100 additional sequenced reads. This level of coverage indicated that the 16S rRNA sequences identified in these groups represent the majority of bacterial sequences present in the samples under study. With the unique sequences analyzed, the species diversity was evaluated with Shannon Index (2.6133 in the CN group Vs. 3.7965 in the BV group) and Simpson Index (0.3793 in the CN group Vs. 0.1240 in the BV group). So, the overall levels of bacterial diversity was significantly different between the BV group and the $\mathrm{CN}$ group ( $p<0.05$ for the two groups, parametric ANOVA for Shannon and Simpson index) (Figure 3), and bacterial communities were significantly different between individuals from the two groups. The vaginal community in the BV group (Evenness $=0.3327$ ) was more even than in the $\mathrm{CN}$ group (Evenness = 0.2185 ) and indicated that bacterial community in the BV group had greater species diversity. All these parameters corroborated each other and confirmed clearly

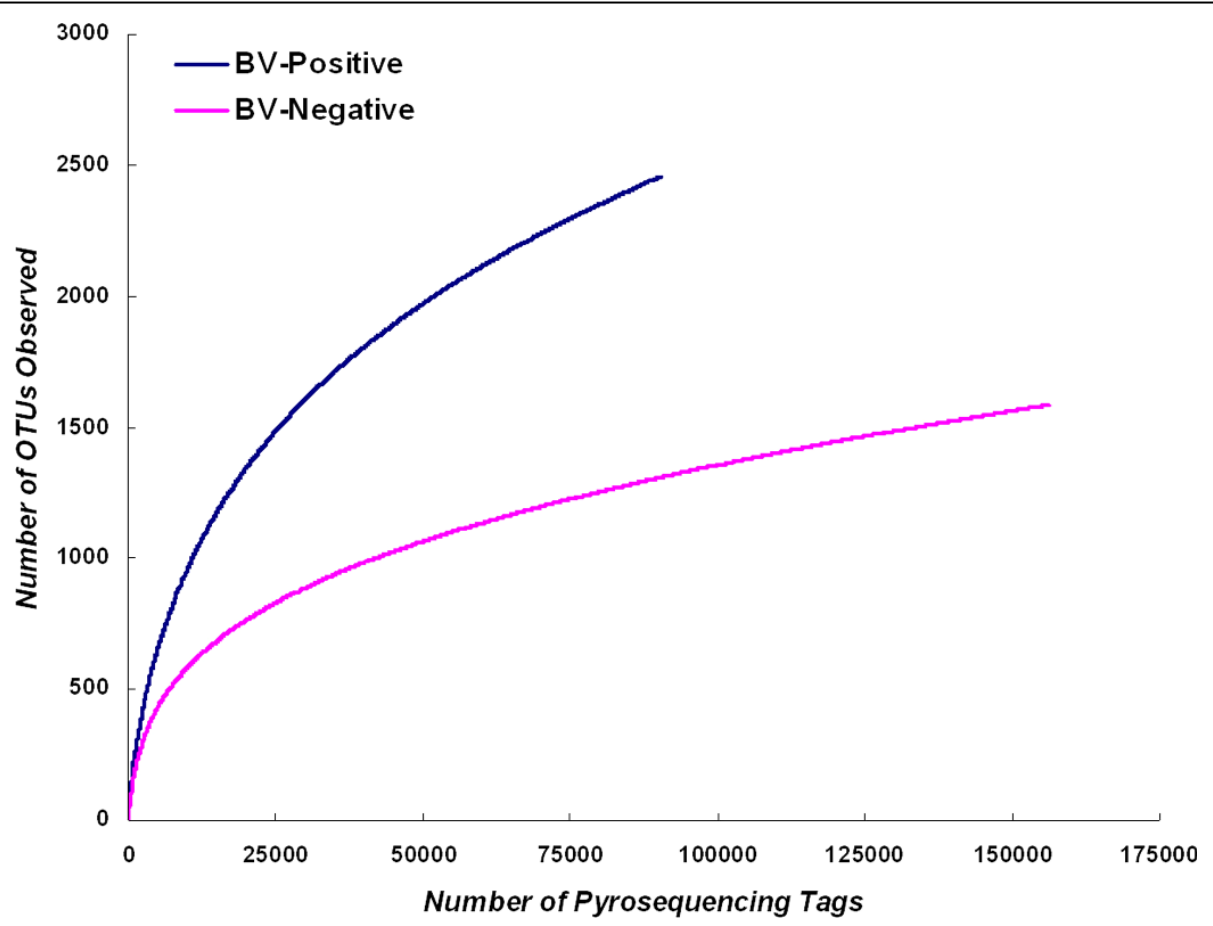

Figure 2 Rarefaction curves were used to estimate richness (in this case the number of taxa at a 3\% dissimilarity level) among BVpositive and BV-negative groups. The vertical axis shows the number of OTUs that would be expected to be found after sampling the number of tags or sequences shown on the horizontal axis. 
Table 1 Comparison of phylotype coverage and diversity estimation of the $16 \mathrm{~S}$ rRNA gene libraries at the $3 \%$ dissimilarity from the pyrosequencing analysis

\begin{tabular}{|c|c|c|c|c|c|c|c|c|c|c|}
\hline Group & Reads & OTUs ${ }^{1}$ & Good $^{2}$ & $A C E$ & 95\% C.I. & Chao & 95\% C.I. & Shannon & Evenness $^{3}$ & Simpson \\
\hline BV-Negative & 156,132 & 1,584 & 0.996 & 2,857 & $(2,714,3,000)$ & 2,500 & $(2,375,2,625)$ & 2.6133 & 0.2185 & 0.3793 \\
\hline BV-Positive & 90,227 & 2,455 & 0.990 & 4,009 & $(3,808,4,209)$ & 3,694 & $(3,509,3,879)$ & 3.7965 & 0.3327 & 0.1240 \\
\hline
\end{tabular}

${ }^{1}$ The operational taxonomic units (OTUs) were defined with $3 \%$ dissimilarity level.

${ }^{2}$ The coverage percentage (Good), richness estimators (ACE and Chao1) and diversity indices (Shannon and Simpson) were calculated using Good's method (Good, 1953) and the MOTHUR program.

${ }^{3}$ The Shannon index of evenness was calculated with the formula $E=H / \ln (S)$, where $H$ is the Shannon diversity index and $S$ is the total number of sequences in that group.

that the vaginal community was more diverse in BV positive women than in BV negative women. The samples in each group or in an individual sample were divided into two clusters based on UniFrac metrics (Figure 4), although there were few BV samples which clustered in the $\mathrm{CN}$ group and vice versa. Although more subclusters existed in the BV group, we found that samples in the BV group formed a large cluster that was very distinct from the $\mathrm{CN}$ group, which was similar to the PCR-DGGE pattern, indicating that they harbored quite different microbial communities.

The phylogenetic classification of sequences from the vagina by phylum is summarized in Figure 5 . The composition and relative abundance of the vaginal microbiota by phylum might be not help one to understand the etiology of BV. However, it did reveal the overall structure of the vaginal microbiota. Eight phyla were found in the vaginal microbiota in women with or without BV. Our data showed that the vast majority of sequences belonged to one of the four major phyla: Bacteroidetes, Firmicutes, Actinobacteria and Fusobacteria. Of these major phyla, Firmicutes was the most dominant phyla in the vaginal microbiota of healthy subjects, while bacteria belonging to Firmicutes, Bacteroidetes, Actinobacteria and Fusobacteria constituted the complex vaginal microbiota in the BV group. The remaining bacteria belonged to the phyla Chloroflexi,
Tenericutes, Proteobacteria and candidate division TM7 (around $0.1-1.0 \%$ of total sequences). The composition of the vaginal microbiota at the phylum level was significantly associated with BV by SPSS with One-Way ANOVA $(p<0.001)$. At the genus level, sequences from the two combined groups represented 116 different genera, with 99 different genera in the BV group and 58 different genera in the $\mathrm{CN}$ group respectively (the taxonomy of the vaginal bacterial communities with RDP classifier showed details in Additional file 1, Table S1). Many genera found in the vaginal community were unexpected, and our results suggest that this is one of the most comprehensive investigations of vaginal microbiota conducted to date (Figure 6). Eleven genera (Lactobacillus, Gardnerella, Atopobium, Megasphaera, Eggerthella, Aerococcus, Alloiococcus, Streptococcus, Leptotrichia/Sneathia, Prevotella and Papillibacter) constituted more than $95 \%$ of the vaginal microbiota. Not surprisingly, our study showed that the genus Lactobacillus constituted the major proportion of vaginal microbiota in healthy women. This confirmed findings from previous studies $[13,14]$.

There was a significant difference between the BV and $\mathrm{CN}$ group in all genera obtained from the vagina. The abundance of Lactobacillus, Alloiococcus, Gardnerella, Atopobium, Megasphaera, Eggerthella, Aerococcus, Leptotrichia/Sneathia, Prevotella and Papillibacter was
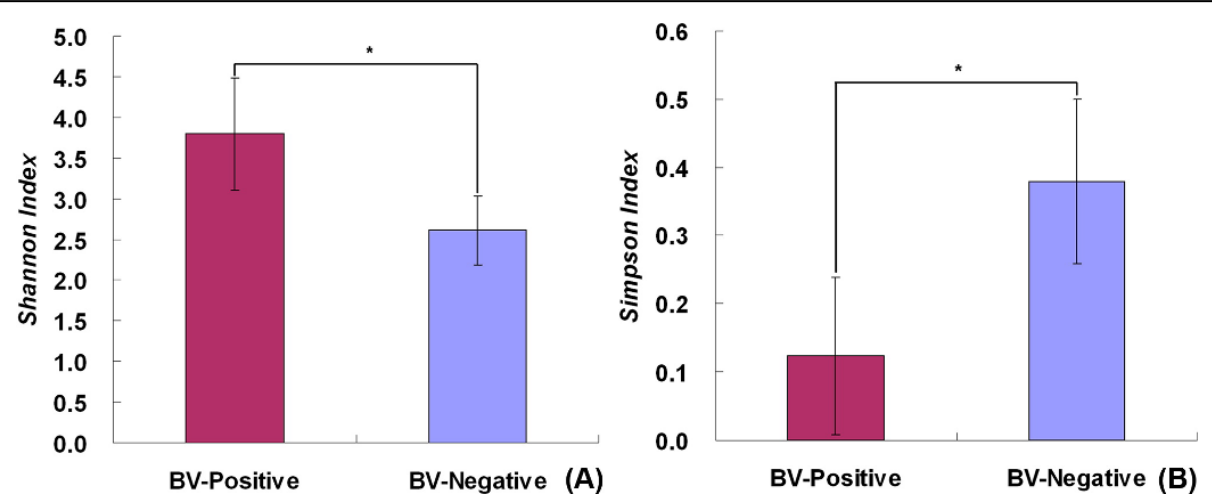

Figure 3 Shannon index and Simpson index were used to estimate diversity (i.e., a combined assessment of the number of $1 \%$ dissimilar bacterial taxa and their abundance) among the eight groups. Data shown as mean with SEM. There were significant differences between BV-positive and BV-negative groups by parametric ANOVA. 




Figure 4 Differentiation in vaginal bacterial communities from 100 individual samples of BV-positive and BV-negative groups (interpersonal variations). Community differentiation was measured by using the unweighted UniFrac algorithm; the scale bar indicates the distance between clusters in UniFrac units. All of the branch nodes shown here were found to be significant $(p<0.001)$, indicating that BVpositive and BV-negative harbored distinct bacterial communities.

significantly different between the two groups $(p<0.05)$ (Figure 7). This indicated that the composition and abundance of the vaginal bacterial communities including these genera played an important role in BV. At the species level, defined as OTUs at the $3 \%$ dissimilarity level, around 1,500 species and about 2,500 species were found in the $\mathrm{CN}$ and BV group, respectively. While at a more conservative level, defined as OTUs at the 5\% dissimilarity level, about 550 phylotypes in the $\mathrm{CN}$ group and about 1,000 phylotypes in the BV group were found. The two groups also shared a great degree of community similarity in the vagina at the $3 \%$ dissimilarity level-about $30 \%$ of the total phylotypes were present in both groups (Figure 8). Our Venn diagrams agree with previous findings that some genera in vaginal communities were not specific for BV, but also existed in the healthy women.

Total bacteria and species-specific qPCR

Our qPCR results supported the pyrosequencing results in terms of which species were associated with BV, although the relative abundance was not in concordance (Additional file 2, Table S2). Consistent with previous findings, we found that $L$. iners was a major component of the vaginal microbiota in healthy women and decreased markedly in BV subjects. Gardnerella, Atopobium, Megasphaera, Eggerthella, Leptotrichia/Sneathia and Prevotella were more common and present at a higher copy numbers in the BV group, although there were significant interpersonal variations (data not shown). Our qPCR revealed the bacterial subgroups that associated significantly with $\mathrm{BV}$ and verified the results of PCR-DGGE and pyrosequencing data. Our quantitative studies of the bacterial species in the vaginal communities demonstrated one common finding: increased numbers of these bacteria were found during the advent of BV. Compared with vaginal microbiota in healthy women, the relative abundance or copy numbers of these bacteria combined with each other was associated with BV significantly and could be potentially used as a molecular marker of microbiota shift in vagina and as a target for diagnosis of BV. 


\begin{tabular}{|l|l|l|l|}
\hline & \\
\hline
\end{tabular}

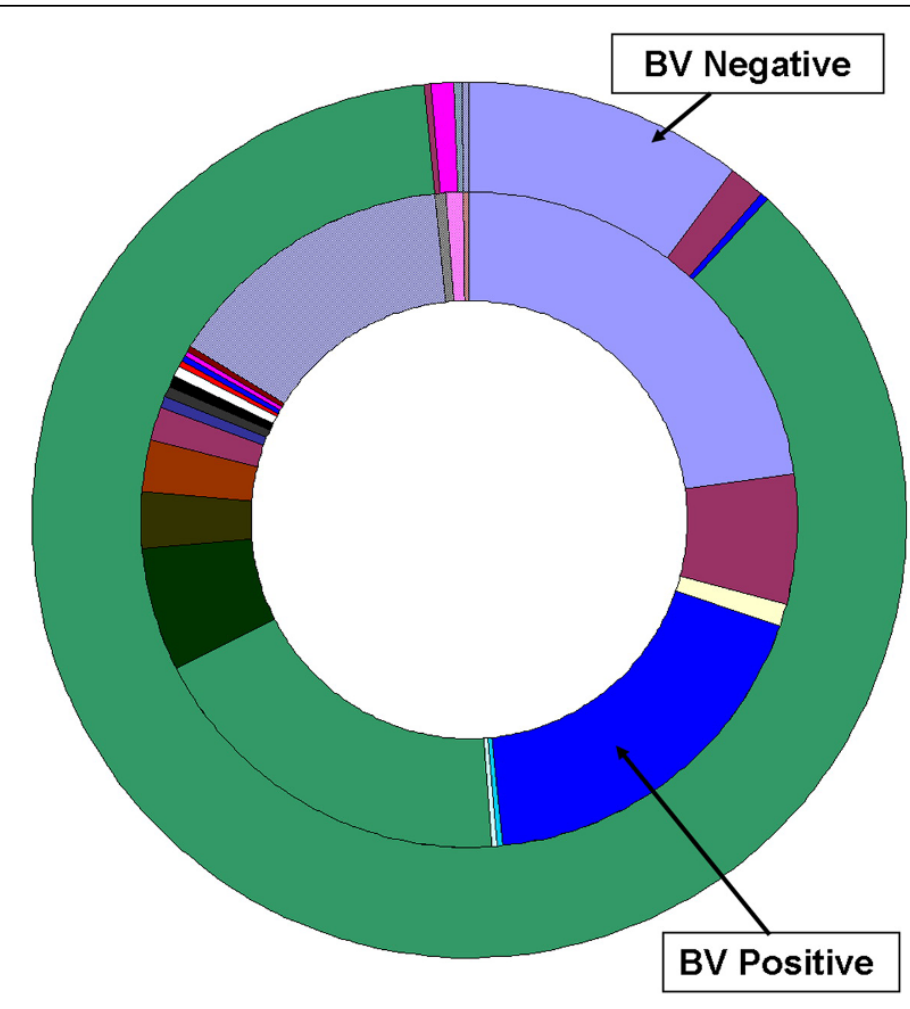

\begin{tabular}{|c|c|}
\hline 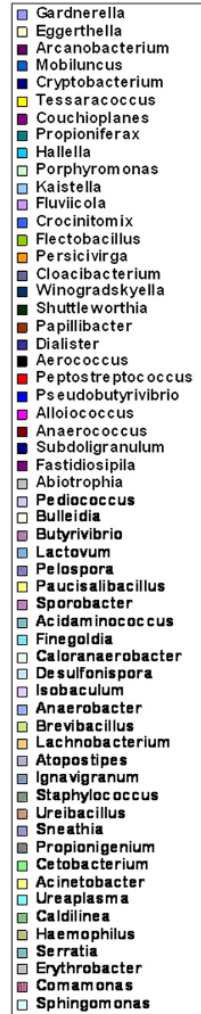 & 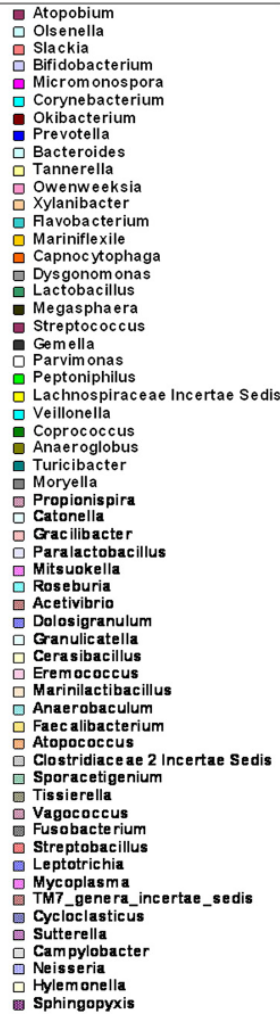 \\
\hline
\end{tabular}

Figure 6 The relative abundance of vaginal bacterial V3 tags obtained by pyrosequencing from BV-positive and BV-negative individuals, by genus and profiled the overall structure of vaginal communities. 


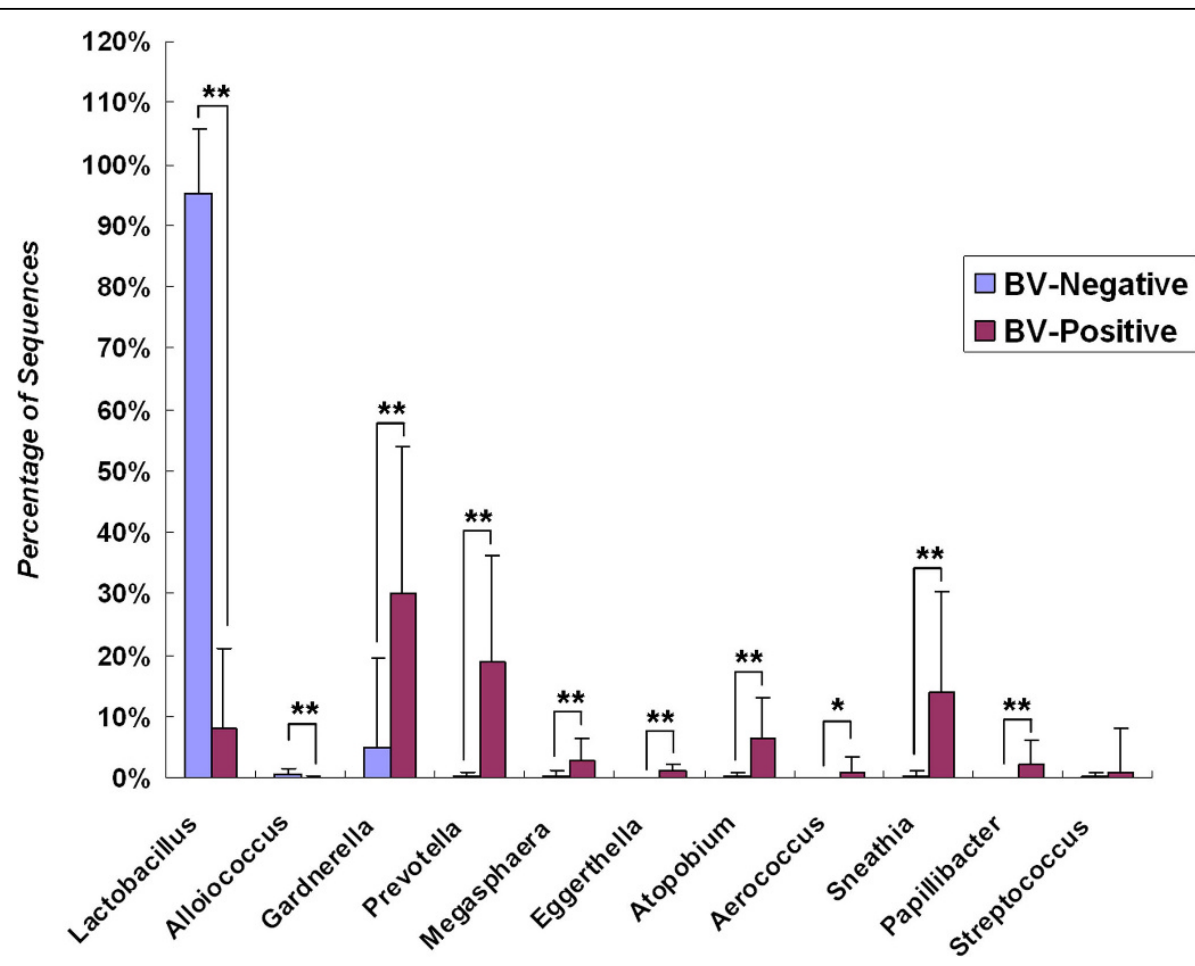

Figure 7 Predominant genera detected in vagina from BV-positive and BV-negative individuals. Among these predominant genera, Lactobacillus, Gardnerella, Atopobium, Alloiococcus, Sneathia, Prevotella, Papillibacter, Megasphaera, Eggerthella, Aerococcus were associated with BV significantly $\left({ }^{*} p<0.05,{ }^{* *} p<0.01\right.$ ). Except for Lactobacillus and Alloiococcus, which were detected at a higher level, other genera were more abundant in BV-positive individuals.

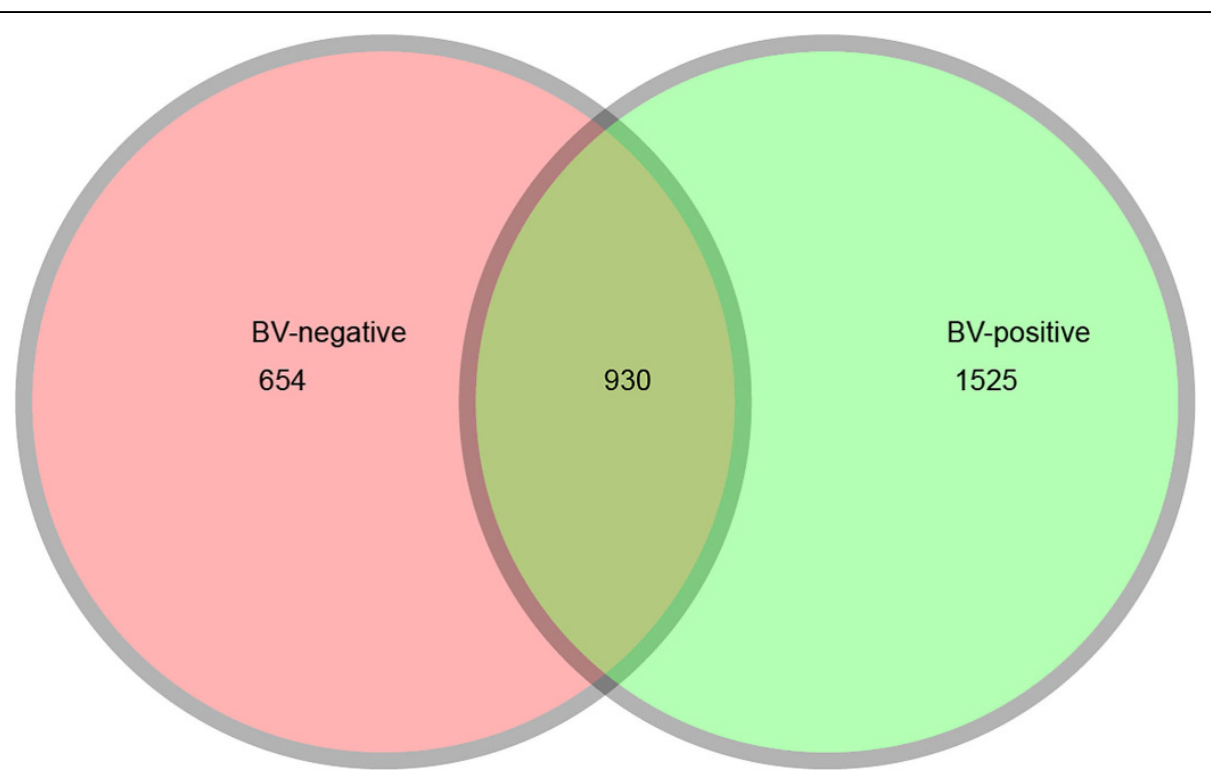

Figure 8 Venn diagrams for overlap between BV-positive observed OTUs versus BV-negative observed OTUs. The Venn diagrams show the overlap in all OTUs calculated at the $3 \%$ dissimilarity level. The number of species in group BV-positive is 2,455. The number of species in group BV-negative is 1,584. The number of species shared between groups BV-positive and BV-negative is 930 . Percentage of species that are shared in groups BV-positive and BV-negative is $29.91 \%$. 
Comparison of pyrosequencing with PCR-DGGE analysis The bacterial diversity of vaginal microbiota was analyzed by PCR-DGGE fingerprinting and barcoded pyrosequencing. These phylotypes detected in the vagina matched each other with two molecular analytical methods. PCRDGGE fingerprinting, which is a conventional molecular ecological approach, only detected the predominant microbiota (Lactobacillus, A. vaginae, uncultured Sneathia sp., F. nucleatum subsp., uncultured Eggerthella sp., and uncultured Megasphaera sp.) in the vagina, and these phylotypes were also abundant in the 454 pyrosequencing reads. However, the bacterial communities determined with the pyrosequencing analysis were more diverse than those communities determined with the PCR-DGGE analysis, as there were more phylotypes revealed with the pyrosequencing analysis than with PCR-DGGE fingerprinting. As we could not excise and sequence all bands in the DGGE profiles, several dominant bands were missed, of which might contain some predominant bacteria such as $G$. vaginalis in the vaginal communities. Pyrosequencing provided a high-throughput approach to analyze the 16S rRNA gene sequences and explore bacterial diversity in different microhabitats deeply, which can compensate for the disadvantage with the PCR-DGGE method in detecting minor populations in microbiota. As only predominant microbiota could be detected by PCR-DGGE, band richness could not reveal the overall extent of bacterial diversity in the vagina. With clustering analysis using the UniFrac algorithm, we found similar cluster profiles in the two groups. The samples in the BV and $\mathrm{CN}$ group were divided into two clusters respectively (Figure 1B and Figure 4). To analyze bacterial diversity, PCR-DGGE fingerprinting and highthroughput pyrosequencing were two important and useful methods, which could corroborate one another.

\section{Discussion}

An understanding of the composition and richness of the vaginal microbial ecosystem in relation to vaginal health is essential for comprehensively understanding the etiology of vaginal diseases, and for the prevention and treatment of these diseases. We analyzed the vaginal communities of healthy participants and women with clinically defined BV which was diagnosed by Amsel criteria and clearly confirmed by Nugent criteria with Nugent score $\geq 7$. Indeed, few of these subjects were asymptomatic $\mathrm{BV}$, where the shift of vaginal microbiota has occurred but the symptoms are absent. However, both the Gram staining and PCR-DGGE verified our diagnosis. Although there are several previous studies that focus on the vaginal microbiota in health and disease or in different races, molecular analysis such as the broad-range PCR assays, terminal restriction fragment length polymorphisms (T-RFLPs) and PCR-clone library analysis still cannot demonstrate the overall structure and composition of vaginal microbiota comprehensively $[13,14,54]$. In fact, the depth of the bacterial diversity in a specific microhabitat is strongly influenced by the total number of sequences that are used for analysis [47]. These previous studies obtained only hundreds of reads for each sample which severely limited the depth of understanding of the overall structure of vaginal microbiota. However, pyrosequencing of the 16S rRNA gene amplicons for microbial community profiling can, for equivalent costs, yield more than two orders of magnitude more sensitivity than traditional PCR cloning and Sanger sequencing [55]. In our study, multiplex barcoded pyrosequencing analysis enabled us to analyze an increased number of samples at a time, to obtain more reads in a single run, to monitor the sequencing error rate, and to perform in-depth analyses for studies of comparative microbial ecology. Although the pyrosequencing read lengths of the sequences were significantly short compared with the sequences obtained with traditional Sanger sequencing methods (600-800bp), these short sequences (about 145bp in our study) provided not only excellent coverage but also excellent recovery for classification at the genus level [56]. In addition, the $145 \mathrm{bp}$ in the highly variable region V3 of the 16S rRNA gene had good discerning power (provided that a $1 \mathrm{bp}$ difference in the $16 \mathrm{~S}$ rRNA gene sequences differentiated the reads by $0.55 \%$ for bacteria) and were long enough to be sufficient for assigning the taxa [48]. Engelbrektson et al. (2010) have shown that for a given number of reads, shorter 16S rRNA gene amplicons yield greater species richness than do longer amplicons. Approximately 100bp amplicons produced significantly higher estimates of richness than $400 \mathrm{bp}$ or 1,000bp products did [57]. All indicated that multiplex parallel pyrosequencing offered a highly automated, rapid, economical and accurate method for the analysis of bacterial diversity. Our study represents one of the most extensive investigations of bacterial diversity in the vagina.

With 454 pyrosequencing analysis, we found that the vaginal bacterial diversity in participants with BV was remarkably high and much greater than previously reported with culture-independent approaches such as PCR-DGGE and cloning and sequencing $[13,14,37$, $39,58]$ and similar with the deep-sequencing techniques by Spear et al. (2008) [59]. The higher number of phylotypes in BV positive women over healthy was consistent with the results of previous studies, and most of which were previously uncultivated species and undiscovered novel phylotypes in the vagina. Compared with other molecular methods for microbiota diversity analysis such as cloning and sequencing approaches, we observed higher bacterial diversity by high-throughput 
parallel pyrosequencing analysis (Good's coverage more than $99.0 \%)[13,54,60]$. The rarefaction curves were still not saturated at the $3 \%$ dissimilarity level even if more than 150,000 sequences in the $\mathrm{CN}$ group were retrieved, which indicated that more sequencing effort should be undertaken to obtain the saturation of the curves. However, the Good's coverage of more than $99.0 \%$ of our study showed that we had obtained almost all bacterial species in the vaginal communities. Recently, a computational model revealed that more than 9 million unique genes were likely to be present in the human gut bacterial community. It was far more rich than had been expected [61]. Based on more pyrosequencing reads and good coverage, that's why the depth of the vaginal communities in our study was superior to those previous studies $[13,14,54,58,59]$. Other diversity indices shown in Table 1, such as Shannon index, Chao1 and ACE, were also higher in the BV group than in the $\mathrm{CN}$ group at the same dissimilarity level. Furthermore, for each sample analyzed in our study, these diversity indices showed significantly interpersonal variations even in the same group (data not shown), similar to that observed for the gastrointestinal tract and human skin $[40,62,63]$. The variation might be due to hormone levels, personal hygiene behavior and even diet [64-66]. Although there were pronounced interpersonal variations in the bacterial community composition of the vagina, the participants also shared a great degree of community similarity in each group and the overall structure of the vaginal bacterial communities in the two groups was obviously divided into two clusters.

Our study represents one of the most extensive examinations of bacterial diversity in the vagina. We demonstrated in this research that BV was associated with compositional changes in the vaginal microbiota mostly apparent at high taxonomic level (phylum) and even genus level. From the eight phyla that we observed in the vaginal ecosystem, Firmicutes constituted the vast majority of vaginal microbiota in healthy women, while Bacteroidetes, Actinobacteria and Fusobacteria were strongly associated with BV. It is not surprising that the predominant bacterial populations in the healthy vagina contained lactic acid bacteria (mainly the genus of Lactobacillus) [67] because these genera can maintain a low vaginal $\mathrm{pH}$ through their metabolic activity and thereby play a role in colonization resistance providing protection against invasion by overt pathogens or against overgrowth and dominance by potentially pathogenic species among the normal microbiota [68-70]. However, the genera of Alloiococcus (member of the lactic acid bacteria), which was previously an unrecognized common member of the healthy vaginal ecosystem, was detected more frequently as normal microbiota in the healthy women in our study. Our data firstly indicated that the members of Alloiococcus along with members of the Lactobacillus might contribute to maintaining the balance of the healthy vaginal ecosystem. Extensive diversity within the Lactobacillus species complex of the vagina has been observed in previous studies. With species-specific qPCR, we also found that L. iners was one of the most abundant vaginal Lactobacillus species in healthy women, while about 100 to 1000-fold copies declined or were even absent in the subjects with BV. Research has shown that L. iners is a dominant part of the vaginal microbiota when in a transitional stage between abnormal and normal health, either because of treatment or because of physiological changes such as varying estrogen levels $[71,72]$. As a result, $L$. iners could be considered as even more typical for normal vaginal microbiota and be a sensitive marker of changes in the vaginal microbiota. Other species of Lactobacillus such as L. crispatus and L. jensenii were also commonly detected Lactobacillus species in the vaginal microbiota but at a lower relative abundance. Previously, L. crispatus has been suggested to be more often linked with health and L. iners with disease [72]. However, no clear quantitative support was found for this claim in our study.

The onset of BV is marked by a decline in the Lactobacillus species and other facultative or anaerobic species as the vaginal microbial ecosystem changes from eubiosis to dysbiosis [73]. In our study, eight BV-related genera, i.e., Gardnerella, Atopobium, Megasphaera, Eggerthella, Aerococcus, Leptotrichia/Sneathia, Prevotella and Papillibacter, were detected at higher prevalence and higher relative abundance in women with BV. These genera included pathogenic species that participated in BV progression. Previous studies have shown that $G$. vaginalis (belonging to Actinobacteria), was found in most subjects with BV and showed higher sensitivity for the diagnosis of BV $[14,33,74]$, but our data also found this species in subjects with low abundance level who did not have BV. This suggests that this species cannot be used as a specific marker for this disease. The difference might be associated with the depth of the pyrosequencing method. Despite its nonspecific discrimination between $\mathrm{BV}$ and $\mathrm{CN}$, we did observe that it was one of most important species in the vaginal communities that associate with BV. Another genus in Actinobacteria, Atopobium, which plays an important role in the development of BV and treatment failure, is highly abundant in the vaginal microbiota of BV [35]. Our pyrosequencing study showed that Atopobium is present in a significant proportion (84\%) of women clinically diagnosed as having BV, but in only $22 \%$ women in $\mathrm{CN}$ group $(p<0.05)$. Although Atopobium was also a lactic acid bacterium, its cellular morphology and role was distinctly different from that of Lactobacillus [75]. With this aspect, Bradshaw et al. (2006) suggested that 
Atopobium was even more specific than G. vaginalis in BV (77\% and 35\%, respectively) [76]. Our results also confirmed this implication. Eggerthella, like A. vaginae in this phylum, was strongly correlated with BV. Tamrakar et al. (2007) reported that the presence of Eggerthella was an independent risk factor of BV scores (Nugent score $\geq 7$ ) [77]. In our study, we highlighted this genus in the vaginal bacterial community in the process of BV. Many studies have shown that Mobiluncus (belonging to Actinomycetaceae in the phylum of Actinobacteria) was found in vaginal bacterial communities only when BV was present, and had a high-level resistance to metronidazole [78]. However, we obtained only low abundance of this genus in our study, which was consistent with a previous study [60]. Other members of the Firmicutes, Megasphaera (especially Megasphaera type区), Aerococcus and Papillibacter, were also associated with BV significantly, although these genera could not be detected in all BV samples. However, the clinical significance of these genera in the vaginal ecosystem is still unknown. Previous work has shown that Megasphaera type区 appeared to have a stronger association with BV than type $\otimes[79]$. We also found that Megasphaera type区was common in BV patients and those two unfamiliar genera of Aerococcus and Papillibacter in vaginal bacterial communities were obviously correlated with BV for the first time. Prevotella (belonging to Bacteroidetes), one of the recently identified predominant microbiota in the complex vaginal communities of BV subjects, was significantly associated with BV in our qPCR and pyrosequencing studies $(p<0.05)$. Prevotella was dramatically higher (7 orders of magnitude) in almost all patients with the clinically defined BV in our qPCR experiment. Our data showed that Prevotella spp. were more common and abundant than other BV-associated genera in the vagina. Ammonia flow from Prevotella to G. vaginalis has been demonstrated and a commensal relationship proposed [80]. It might be implicated that Prevotella showed a synergistic effect with G. vaginalis and aggravated the process of BV. The combination of bacterium-specific PCR assays for Prevotella and G. vaginalis might improve sensitivity or specificity for the diagnosis of BV. Leptotrichial Sneathia (belonging to Fusobacteria), which was also a lactic acid-producer, was strongly associated with BV in our study. However, there was little known about the ecology of this genus. Fredricks et al. (2005) showed that detection of Leptotrichia species was very specific for BV by bacterium-specific PCR assays [14]. Our observations in qPCR and pyrosequencing studies showed that the prevalence of Leptotrichia/Sneathia in BV patients was higher than in $\mathrm{CN}$ subjects. It could be a new marker of BV in the pathogenic vaginal communities like others mentioned above. Compared with the ten predominant genera, other bacteria identified from the complex vaginal bacterial communities were detected at low relative abundance.
Some have been detected in the vagina before, but most of them were first found in our study.

However, there were also some limitations to our study. First, there was no analysis of Nugent score and $\mathrm{pH}$ in relation to the change of vaginal community structure and composition as participants diagnosed as BV in our study were almost with Nugent score $\geq 7$ and a $\mathrm{pH}$ of vaginal discharge $\geq 4.5$. For such an analysis it would be necessary to explore the relationship between intermediate vaginal microbiota $(4 \leq$ Nugent score $<7)$ and asymptomatic BV. Second, we did not explore the dynamics of vaginal bacterial communities in the process of BV and the bacterial diversity for re-establishment of vaginal microbiota after effective treatment by the high-throughput pyrosequencing. Further studies of the vaginal microbiota-host interplay, especially those bacteria found in our study with low relative abundance and its influence on local vaginal immunity, will be necessary in order to understand extensively the ecological role of the complex vaginal bacterial communities in the BV process. This new insight into the overall structure of vaginal community in BV may provide fundamental information for future investigations.

\section{Conclusions}

Our results elucidated that vaginal microbiota are more diverse in BV participants than we expected before. This provides novel insights into the vaginal microbiota in the etiology of BV and confirms that the barcoded pyrosequencing approach can be a powerful tool for characterizing the microbiota in vaginal ecosystems compared with classical molecular ecological approaches, such as PCR-DGGE. The study represents one of the most extensive examinations of bacterial diversity in the vagina. We observed that at a high taxonomic level, the phylum of Bacteroidetes, Actinobacteria and Fusobacteria were significantly associated with BV. Although no single bacterium can be identified as uniquely associated with $\mathrm{BV}$, our data indicated that the vaginal communities including Gardnerella, Atopobium, Megasphaera, Eggerthella, Aerococcus, Leptotrichial Sneathia, Prevotella and Papillibacter were clearly associated with BV. These genera in the vaginal communities were potentially excellent markers of BV and could be used as targets for BV diagnosis by molecular approaches alone or in combination. Our results have provided a comprehensive picture of our current knowledge of the community structure of the vaginal bacterial ecosystem and have significantly increased current understanding of the etiology of BV. Continuing exploration of vaginal bacterial communities and host interplay in different healthy and diseased states will shed light on the BV susceptibility and provide new insights for treatment. 


\section{Methods}

\section{Subject Selection}

One hundred women with regular menstrual cycles (2435 days) aged 19 to 51 years, including $50 \mathrm{BV}$ positive women (BV group, aged $33.3 \pm 9.1$ ) and 50 healthy control women ( $\mathrm{CN}$ group, aged $32.0 \pm 8.1$ ), who came to the Department of Obstetrics and Gynecology of the First Affiliated Hospital, College of Medicine, Zhejiang University for routine gynecology examination from October 2008 to May 2009, were recruited for this study. Informed written consent was obtained from all participants prior to enrollment, with approval of the ethical committee of the First Affiliated Hospital, College of Medicine, Zhejiang University, Zhejiang province, China. Individuals who participated in this study were examined by two gynecologists. BV status was assessed using Amsel clinical criteria for all subjects [81] and confirmed using Gram stain criteria (Nugent scores) [82]. Only participants with Nugent score $\geq 7$ were selected for the following analysis. Any participant having any of the following exclusion criteria was excluded from participation: $<18$ years of age, pregnancy, diabetes mellitus, the use of antibiotics or vaginal antimicrobials (orally or by topical application in vulvar/vaginal area) in the previous month, menstruation, presence of an intrauterine device, vaginal intercourse within the latest 3 days, known active infection due to Chlamydia, yeast, $N$. gonorrhoeae, or $T$. vaginalis, clinically apparent herpes simplex infection, or defined diagnosed HPV, HSV-2, or HIV-1 infection. (The clinical data for each participant were shown in Additional file 3, Table S3). The participants who met three or more of the following criteria were clinically diagnosed as BV: homogenous vaginal discharge, $>20 \%$ clue cells on wet mount, elevated $\mathrm{pH}(\geq 4.5)$ of vaginal discharge, and release of a fishy amine odor upon addition of $10 \%$ potassium hydroxide solution to vaginal fluid ("whiff" test) [81]. Then based on the criteria for BV assessment developed by Nugent et al. [82], participants with the Gram stain score of $\geq 7$ were finally confirmed as BV. Participants without these changes were defined as the healthy control group.

\section{Sample Collection and Preparation}

When women underwent genital examination, 2 swabs from each woman were taken near the mid-vagina using a sterile swab, packaged and placed in ice packs. (Kim et al. (2009) [83] have revealed that the vaginal microbiota is not homogenous throughout the vaginal tract but differs significantly within an individual with regard to anatomical site and sampling method used.) The first swab was rolled onto a slide for Gram staining; the second vaginal swab was used for bacterial genomic DNA extraction. The vaginal swabs for bacterial genomic DNA extraction were transferred to the laboratory immediately in an ice-box, and stored at $-80^{\circ} \mathrm{C}$ after preparation within $15 \mathrm{~min}$ for further analysis.

\section{Total bacterial genomic DNA extraction}

The bacterial cells retrieved on swabs were submerged in $1 \mathrm{ml}$ of sterile normal saline (prepared with RNase free $\mathrm{H}_{2} \mathrm{O}, \mathrm{pH}$ 7.0) and vigorously agitated to dislodge cells. The cells were pelleted by centrifugation (Thermo Electron Corporation, Boston, MA, USA) at full speed ( $\geq 10,000 \mathrm{~g}$ ) for $10 \mathrm{~min}$, washed by re-suspending cells in sterile normal saline and centrifuged at full speed for $5 \mathrm{~min}$. Then bacterial DNA was extracted from the vaginal swabs using QIAamp DNA Mini Kit (QIAGEN, Hilden, Germany) according to manufacturer's instructions with minor modification. Briefly, the bacterial pellet was suspended in $180 \mu \mathrm{l}$ of lysis buffer (buffer ATL) and homogenized by vortexing. A total of $20 \mu \mathrm{l}$ of a proteinase $\mathrm{K}$ solution $(20 \mathrm{mg} / \mathrm{ml})$ and $100 \mathrm{mg}$ of zirconium beads $(0.1 \mathrm{~mm})$ were then added. The mixtures were agitated in a mini bead beater (FastPrep, Thermo Electron Corporation, USA) three times, $40 \mathrm{~s}$ each time, and incubated at $56^{\circ} \mathrm{C}$ for approximately $40 \mathrm{~min}$. $200 \mu \mathrm{l}$ of the second lysis buffer (buffer $\mathrm{AL}$ ) provided in the kit was added, and the sample was incubated at $70^{\circ} \mathrm{C}$ for $10 \mathrm{~min}$. Next, $200 \mu \mathrm{l}$ of ethanol was added; this mixture was then loaded on the QIAamp spin column and centrifuged at 8,000 $\mathrm{g}$ for $1 \mathrm{~min}$. The QIAamp spin column was placed in a new $2 \mathrm{ml}$ collection microtube, and the containing filtrate was discarded. The column material was washed with $500 \mu \mathrm{l}$ buffer AW1 and with $500 \mu \mathrm{l}$ buffer AW2 provided in the kit. Finally, the DNA was eluted with $20 \mu \mathrm{l}$ of distilled water $(2 \times 10 \mu \mathrm{l})$. The concentration of extracted DNA was determined by using a NanoDrop ND-1000 spectrophotometer (Thermo Electron Corporation, USA); its integrity and size were checked by $1.0 \%$ agarose gel electrophoresis containing $0.5 \mathrm{mg} / \mathrm{ml}$ ethidium bromide. All DNA was stored at $-20^{\circ} \mathrm{C}$ before further analysis.

\section{PCR-DGGE analysis}

Universal bacterial primers $341 \mathrm{~F}$ and $534 \mathrm{R}$ for the V3 regions of $16 \mathrm{~S}$ rRNA genes were used to amplify approximately $200 \mathrm{bp}$, based on positions 341 to 534 of the Escherichia coli $16 \mathrm{~S}$ rRNA gene, as described by Muyzer et al. (1993) [38,51]. The reaction conditions were those as described previously by Li et al. (2008) [41] with minor modifications. The DGGE analysis (with $35 \%$ to $50 \%$ gradient) and the sequence analysis of the excised DGGE bands was performed as described [41]. The similarities of PCR-DGGE DNA profiles were analyzed with Quantity One ${ }^{\bullet} 1$-D Analysis software 
(version 4. 6.2; Bio-Rad Laboratory, Hercules, CA, USA). A similarity matrix was constructed using Dice's similarity coefficient. A dendrogram was constructed by the unweighted pair group method, using arithmetic averages (UPGMA) (details in Additional file 4, Supplementary Information).

\section{4 pyrosequencing and data analysis}

PCR amplification of the 16S rRNA gene hypervariable V3-region was performed with universal bacterial primers (It must be noted that 454 adaptor sequences and barcodes are not shown here): 341F (5'-ATTACCGC GGCTGCTGG -3') and 534R (5'-CCTACGGGAGGCAGCAG -3') (details in Additional file 4, Supplementary Information) as described [48]. Amplicon pyrosequencing was performed with standard 454/Roche GS-FLX protocols [84]. After pyrosequencing, all reads were screened and filtered for quality and length using customized Perl scripts written by ourselves. Raw sequences were processed and analyzed following the procedure described previously [43]. Approximately $23.3 \%$ of the total raw pyrosequencing reads was not passed quality control. Sequences were assigned to samples by examining the 8 -bp barcode (Additional file 5, Table S4) [85]. The qualified 16S rRNA gene fragments were processed as previously described [86]. OTUs and OTU rarefaction curves were created by aligning unique tag sequences and used to determine richness and diversity indexes (Shannon Weaver and Simpson diversity indices), ACE, Chao1, Good's coverage at each dissimilarity level using MOTHUR (version 1.5.0) http:// schloss.micro.umass.edu/[87]. Read level taxonomic assignments were performed using the Ribosomal Database Project (RDP) Classifier program http://rdp.cme. msu.edu/[88] with an $80 \%$ bootstrap score. Community comparative analysis was performed using the webbased service UniFrac [89]. The neighbor-joining tree was constructed using the MEGA 4.0 program based on the Jukes-Cantor model and used for UniFrac analysis. The statistical significance of differences in microbial community composition, and Shannon and Simpson index between sample categories was determined by SPSS with One-Way ANOVA (details in Additional file 4, Supplementary Information).

\section{Validation of the relative abundance of vaginal microbiota with qPCR}

To estimate the accurate copy numbers of total Bacteria and bacterial subgroups in the samples, and to validate the relative abundance of genus-specific bacteria as determined by 454 pyrosequencing. 16S rRNA gene-targeted qPCR (species-specific primers in Additional file 6, Table S5) was performed with a Power SYBR Green PCR Master Mix (Takara, Dalian, China) on an ABI
7900 Real-time PCR instrument according to the manufacturer's instructions (Applied Biosystems, Foster city, CA). Details of the standards and PCR conditions are provided in Additional file 4, Supplementary Information.

\section{Additional material}

\section{Additional file 1: Table S1. The taxonomy of vaginal bacterial} communities with RDP Classifier. Taxonomic assignments at the genus level were made with a bootstrap confidence range at $\geq 80 \%$ using the RDP Classifier.

Additional file 2: Table S2. The abundance of vaginal bacteria relative to total Bacteria gene copy number by species-specific qPCR. Comparisons of the relative abundance of the specific bacteria in the vagina between women with BV and women without BV were calculated with independent-samples T-tests (SPSS Data Analysis Program version 16.0, SPSS Inc, Chicago, IL) and were considered statistically significant if $p<0.05$. These $\mathrm{APCR}$ results supported the pyrosequencing results in terms of which species were associated with BV, although the relative abundance was not in concordance.

Additional file 3: Table S3. The Clinical Data for Each Participant 100 subjects (50 women with BV and 50 women without BV) that participated in our study were diagnosed with Amsel clinical criteria and Nugent criteria.

Additional file 4: Supplementary Information. Supplemental materials and methods used in our study.

Additional file 5: Table S4. List of the 100 8-bp barcodes used to tag each PCR product analyzed as part of the study. Table of 8-bp barcodes used to identify each sample from the sample pool.

Additional file 6: Table S5. Species-specific primer sets for detection of vaginal bacteria by qPCR. Table of primers used in this study to carry out real-time PCR analysis of total bacteria and 10 bacterial species in the vagina.

\section{Acknowledgements}

This present work was funded by the grants of National Basic Research Program of China (973 program) Grant 2007 CB513001 and partly supported by grants from China's National Science and Technology Major Project (No. 2008ZX10004-002, No. 2009ZX10004-105) and a Qiu-Shi Scholarship from Zhejiang University. We thank Barbara Nelson for her critical reading of our manuscript.

\section{Author details}

${ }^{1}$ State Key Laboratory for Diagnosis and Treatment of Infectious Diseases, the First Affiliated Hospital, College of Medicine, Zhejiang University, Hangzhou, Zhejiang, 310003, China. ${ }^{2}$ Zhejiang-California International Nanosystems Institute (ZCNI), Zhejiang University, Hangzhou, Zhejiang, 310029, China. ${ }^{3}$ Department of Obstetrics and Gynecology, the First Affiliated Hospital, College of Medicine, Zhejiang University, Hangzhou, Zhejiang, 310003, China. ${ }^{4}$ Chinese National Human Genome Center at Shanghai, Shanghai, 201203, China. ${ }^{5}$ J. Craig Venter Institute, 9704 Medical Center Drive, Rockville, Maryland 20850, USA.

\section{Authors' contributions}

ZXL conducted the experimental design, sample collection, PCR-DGGE, realtime PCR, barcodes design, analyzed results and wrote the paper. JMK carried out experimental design, samples collection, barcodes design, PCR amplification and analyzed results. FL, HBZ and YXX participated in sample collection and partial data analysis. $X Y C$ carried out quantitative real-time PCR and data analysis. YZW carried out partial data analysis. LL, KEN, YXX and CX conceived of the study, and participated in its design and coordination and helped to draft the manuscript. All authors read and approved the final manuscript. 
Received: 12 April 2010 Accepted: 7 September 2010

Published: 7 September 2010

\section{References}

1. Dethlefsen L, McFall-Ngai M, Relman DA: An ecological and evolutionary perspective on human-microbe mutualism and disease. Nature 2007, 449:811-818.

2. Turnbaugh PJ, Ley RE, Hamady M, Fraser-Liggett $C M$, Knight $R$, Gordon Jl: The human microbiome project. Nature 2007, 449:804-810.

3. Gill SR, Pop M, Deboy RT, Eckburg PB, Turnbaugh PJ, Samuel BS, Gordon Jl, Relman DA, Fraser-Liggett CM, Nelson KE: Metagenomic analysis of the human distal gut microbiome. Science 2006, 312:1355-1359.

4. Cash HL, Whitham CV, Behrendt CL, Hooper LV: Symbiotic bacteria direct expression of an intestinal bactericidal lectin. Science 2006, 313:1126-1130.

5. Ley RE, Peterson DA, Gordon J: Ecological and evolutionary forces shaping microbial diversity in the human intestine. Cell 2006, 124:837-848.

6. Ley RE, Turnbaugh PJ, Klein S, Gordon Jl: Microbial ecology: human gut microbes associated with obesity. Nature 2006, 444:1022-1023.

7. Mazmanian SK, Liu CH, Tzianabos AO, Kasper DL: An immunomodulatory molecule of symbiotic bacteria directs maturation of the host immune system. Cell 2005, 122:107-118.

8. Turnbaugh PJ, Ley RE, Mahowald MA, Magrini V, Mardis ER, Gordon J: An obesity-associated gut microbiome with increased capacity for energy harvest. Nature 2006, 444:1027-1031.

9. Rosenstein IJ, Morgan DJ, Sheehan M, Lamont RF, Taylor-Robinson D: Bacterial vaginosis in pregnancy: distribution of bacterial species in different gram-stain categories of the vaginal flora. J Med Microbiol 1996, 45:120-126.

10. Antonio MA, Hawes SE, Hillier SL: The identification of vaginal Lactobacillus species and the demographic and microbiologic characteristics of women colonized by these species. J Infect Dis 1999, 180:1950-1956.

11. Boskey ER, Cone RA, Whaley KJ, Moench TR: Origins of vaginal acidity: high $D / L$ lactate ratio is consistent with bacteria being the primary source. Hum Reprod 2001, 16:1809-1813.

12. Redondo-Lopez V, Cook RL, Sobel JD: Emerging role of lactobacilli in the control and maintenance of the vaginal bacterial microflora. Rev Infect Dis 1990, 12:856-872.

13. Zhou X, Brown CJ, Abdo Z, Davis CC, Hansmann MA, Joyce P, Foster JA, Forney $\downarrow$ : Differences in the composition of vaginal microbial communities found in healthy Caucasian and black women. ISME J 2007, 1:121-133.

14. Fredricks DN, Fiedler TL, Marrazzo JM: Molecular identification of bacteria associated with bacterial vaginosis. N Engl J Med 2005, 353:1899-1911.

15. Schwebke JR: New concepts in the etiology of bacterial vaginosis. Curr Infect Dis Rep 2009, 11:143-147.

16. Kalra A, Palcu CT, Sobel JD, Akins RA: Bacterial Vaginosis: Culture- and PCR-based Characterizations of a Complex Polymicrobial Disease's Pathobiology. Curr Infect Dis Rep 2007, 9:485-500.

17. Schwebke JR: Bacterial Vaginosis. Curr Infect Dis Rep 2000, 2:14-17.

18. Allsworth JE, Peipert JF: Prevalence of bacterial vaginosis: 2001-2004 National Health and Nutrition Examination Survey data. Obstet Gynecol 2007, 109:114-120

19. Wang J: Bacterial vaginosis. Prim Care Update Ob Gyns 2000, 7:181-185.

20. Gravett MG, Hummel D, Eschenbach DA, Holmes KK: Preterm labor associated with subclinical amniotic fluid infection and with bacterial vaginosis. Obstet Gynecol 1986, 67:229-237.

21. Hillier SL, Nugent RP, Eschenbach DA, Krohn MA, Gibbs RS, Martin DH, Cotch MF, Edelman R, Pastorek JG, Rao AV, McNellis D, Regan JA, Carey JC, Klebanoff MA: Association between bacterial vaginosis and preterm delivery of a low-birth-weight infant. The Vaginal Infections and Prematurity Study Group. N Engl J Med 1995, 333:1737-1742.

22. Sweet RL: Role of bacterial vaginosis in pelvic inflammatory disease. Clin Infect Dis 1995, 20(Suppl 2):S271-275.

23. Haggerty $C L$, Hillier SL, Bass DC, Ness RB: Bacterial vaginosis and anaerobic bacteria are associated with endometritis. Clin Infect Dis 2004 39:990-995.
24. Cherpes TL, Meyn LA, Krohn MA, Lurie JG, Hillier SL: Association between acquisition of herpes simplex virus type 2 in women and bacterial vaginosis. Clin Infect Dis 2003, 37:319-325.

25. Wiesenfeld HC, Hillier SL, Krohn MA, Landers DV, Sweet RL: Bacterial vaginosis is a strong predictor of Neisseria gonorrhoeae and Chlamydia trachomatis infection. Clin Infect Dis 2003, 36:663-668.

26. Kaul R, Nagelkerke NJ, Kimani J, Ngugi E, Bwayo JJ, Macdonald KS, Rebbaprgada A, Fonck K, Temmerman M, Ronald AR, Moses S: Prevalent herpes simplex virus type 2 infection is associated with altered vaginal flora and an increased susceptibility to multiple sexually transmitted infections. J Infect Dis 2007, 196:1692-1677.

27. Watts DH, Fazzari M, Minkoff H, Hillier SL, Sha B, Glesby M, Levine AM, Burk R, Palefsky JM, Moxley M, Ahdieh-Grant L, Strickler HD: Effects of bacterial vaginosis and other genital infections on the natural history of human papillomavirus infection in HIV-1-infected and high-risk HIV-1uninfected women. J Infect Dis 2005, 191:1129-1139.

28. Myer L, Kuhn L, Stein ZA, Wright TC Jr, Denny L: Intravaginal practices, bacterial vaginosis, and women's susceptibility to HIV infection: epidemiological evidence and biological mechanisms. Lancet Infect Dis 2005, 5:786-794.

29. Sewankambo N, Gray RH, Wawer MJ, Paxton L, McNaim D, WabwireMangen F, Serwadda D, Li C, Kiwanuka N, Hillier SL, Rabe L, Gaydos CA, Quinn TC, Konde-Lule J: HIV-1 infection associated with abnormal vaginal flora morphology and bacterial vaginosis. Lancet 1997, 350:546-550.

30. Sobel JD: Pathogenesis of Recurrent Vulvovaginal Candidiasis. Curr Infect Dis Rep 2002, 4:514-519.

31. Klebanoff MA, Schwebke JR, Zhang J, Nansel TR, Yu KF, Andrews WW: Vulvovaginal symptoms in women with bacterial vaginosis. Obstet Gynecol 2004, 104:267-272.

32. McDonald HM, Brocklehurst $P$, Gordon A: Antibiotics for treating bacterial vaginosis in pregnancy. Cochrane Database Syst Rev 2007, CD000262.

33. Gardner HL, Dukes CD: Haemophilus vaginalis vaginitis: a newly defined specific infection previously classified non-specific vaginitis. Am J Obstet Gynecol 1955, 69:962-976.

34. Spiegel CA, Eschenbach DA, Amsel R, Holmes KK: Curved anaerobic bacteria in bacterial (nonspecific) vaginosis and their response to antimicrobial therapy. J Infect Dis 1983, 148:817-822.

35. Verstraelen $H$, Verhelst $R$, Claeys $G$, Temmerman M, Vaneechoutte M: Culture-independent analysis of vaginal microflora: the unrecognized association of Atopobium vaginae with bacterial vaginosis. Am J Obstet Gynecol 2004, 191:1130-1132.

36. Hill JE, Goh SH, Money DM, Doyle M, Li A, Crosby WL, Links M, Leung A, Chan D, Hemmingsen SM: Characterization of vaginal microflora of healthy, nonpregnant women by chaperonin- 60 sequence-based methods. Am J Obstet Gynecol 2005, 193:682-692.

37. Schellenberg J, Links MG, Hill JE, Dumonceaux TJ, Peters GA, Tyler S, Ball TB, Severini A, Plummer FA: Pyrosequencing of the chaperonin-60 universal target as a tool for determining microbial community composition. App/ Environ Microbiol 2009, 75:2889-2898.

38. Muyzer G, de Waal EC, Uitterlinden AG: Profiling of complex microbial populations by denaturing gradient gel electrophoresis analysis of polymerase chain reaction-amplified genes coding for 16S rRNA. Appl Environ Microbiol 1993, 59:695-700.

39. Vitali B, Pugliese C, Biagi E, Candela M, Turroni S, Bellen G, Donders GG, Brigidi P: Dynamics of vaginal bacterial communities in women developing bacterial vaginosis, candidiasis, or no infection, analyzed by PCR-denaturing gradient gel electrophoresis and real-time PCR. Appl Environ Microbiol 2007, 73:5731-5741.

40. Grice EA, Kong HH, Conlan S, Deming CB, Davis J, Young AC, Bouffard GG Blakesley RW, Murray PR, Green ED, Turner ML, Segre JA: Topographical and temporal diversity of the human skin microbiome. Science 2009, 324:1190-1192.

41. Li M, Wang B, Zhang M, Rantalainen M, Wang S, Zhou H, Zhang $Y$, Shen J, Pang X, Zhang M, Wei H, Chen Y, Lu H, Zuo J, Su M, Qiu Y, Jia W, Xiao C, Smith LM, Yang S, Holmes E, Tang H, Zhao G, Nicholson JK, Li L, Zhao L: Symbiotic gut microbes modulate human metabolic phenotypes. Proc Natl Acad Sci USA 2008, 105:2117-2122. 
42. Keijser BJ, Zaura E, Huse SM, van der Vossen JM, Schuren FH, Montijn RC, ten Cate JM, Crielaard W: Pyrosequencing analysis of the oral microflora of healthy adults. J Dent Res 2008, 87:1016-1020.

43. Hamady M, Walker JJ, Harris JK, Gold NJ, Knight R: Error-correcting barcoded primers for pyrosequencing hundreds of samples in multiplex. Nat Methods 2008, 5:235-237.

44. Meyer M, Stenzel U, Hofreiter M: Parallel tagged sequencing on the 454 platform. Nat Protoc 2008, 3:267-278.

45. von Bubnoff A: Next-generation sequencing: the race is on. Cell 2008, 132:721-723.

46. Edwards RA, Rodriguez-Brito B, Wegley L, Haynes M, Breitbart M, Peterson DM, Saar MO, Alexander S, Alexander EC Jr, Rohwer F: Using pyrosequencing to shed light on deep mine microbial ecology. BMC Genomics 2006, 7:57.

47. Roesch LF, Fulthorpe RR, Riva A, Casella G, Hadwin AK, Kent AD, Daroub SH, Camargo FA, Farmerie WG, Triplett EW: Pyrosequencing enumerates and contrasts soil microbial diversity. ISME J 2007, 1:283-290.

48. Roh SW, Kim KH, Nam YD, Chang HW, Park EJ, Bae JW: Investigation of archaeal and bacterial diversity in fermented seafood using barcoded pyrosequencing. ISME J 2010, 4:1-16.

49. Fierer N, Hamady M, Lauber CL, Knight R: The influence of sex, handedness, and washing on the diversity of hand surface bacteria. Proc Natl Acad Sci USA 2008, 105:17994-17999.

50. Dowd SE, Sun Y, Secor PR, Rhoads DD, Wolcott BM, James GA, Wolcott RD: Survey of bacterial diversity in chronic wounds using pyrosequencing, DGGE, and full ribosome shotgun sequencing. BMC Microbiol 2008, 8:43.

51. $\mathrm{Yu} Z$ Z, Morrison M: Comparisons of different hypervariable regions of rrs genes for use in fingerprinting of microbial communities by PCRdenaturing gradient gel electrophoresis. Appl Environ Microbiol 2004 70:4800-4806.

52. Binladen J, Gilbert MT, Bollback JP, Panitz F, Bendixen C, Nielsen R, Willerslev E: The use of coded PCR primers enables high-throughput sequencing of multiple homolog amplification products by 454 parallel sequencing. PLoS One 2007, 2:e197.

53. Schloss PD, Handelsman J: Introducing DOTUR, a computer program for defining operational taxonomic units and estimating species richness. Appl Environ Microbiol 2005, 71:1501-1506.

54. Hyman RW, Fukushima M, Diamond L, Kumm J, Giudice LC, Davis RW: Microbes on the human vaginal epithelium. Proc Natl Acad Sci USA 2005, 102:7952-7957.

55. Tringe SG, Hugenholtz P: A renaissance for the pioneering $16 \mathrm{~S}$ rRNA gene. Curr Opin Microbiol 2008, 11:442-446.

56. Liu Z, DeSantis TZ, Andersen GL, Knight R: Accurate taxonomy assignments from $16 \mathrm{~S}$ rRNA sequences produced by highly parallel pyrosequencers. Nucleic Acids Res 2008, 36:e120.

57. Engelbrektson A, Kunin V, Wrighton KC, Zvenigorodsky N, Chen F, Ochman $\mathrm{H}$, Hugenholtz P: Experimental factors affecting PCR-based estimates of microbial species richness and evenness. ISME J 2010, 4:642-647.

58. Zhou X, Bent SJ, Schneider MG, Davis CC, Islam MR, Forney LJ: Characterization of vaginal microbial communities in adult healthy women using cultivation-independent methods. Microbiology 2004, 150:2565-2573.

59. Spear GT, Sikaroodi M, Zariffard MR, Landay AL, French AL, Gillevet PM: Comparison of the diversity of the vaginal microbiota in HIV-infected and HIV-uninfected women with or without bacterial vaginosis. J Infect Dis 2008, 198:1131-1140.

60. Oakley BB, Fiedler TL, Marrazzo JM, Fredricks DN: Diversity of human vaginal bacterial communities and associations with clinically defined bacterial vaginosis. Appl Environ Microbiol 2008, 74:4898-4909.

61. Yang $X$, Xie L, Li Y, Wei C: More than $9,000,000$ unique genes in human gut bacterial community: estimating gene numbers inside a human body. PLoS One 2009, 4:e6074.

62. Eckburg PB, Bik EM, Bernstein CN, Purdom E, Dethlefsen L, Sargent M, Gill SR, Nelson KE, Relman DA: Diversity of the human intestinal microbial flora. Science 2005, 308:1635-1638.

63. Gao Z, Tseng CH, Pei Z, Blaser MJ: Molecular analysis of human forearm superficial skin bacterial biota. Proc Natl Acad Sci USA 2007, 104:2927-2932

64. Farage M, Maibach $\mathrm{H}$ : Lifetime changes in the vulva and vagina. Arch Gynecol Obstet 2006, 273:195-202.
65. Neggers YH, Nansel TR, Andrews WW, Schwebke JR, Yu KF, Goldenberg RL, Klebanoff MA: Dietary intake of selected nutrients affects bacterial vaginosis in women. J Nutr 2007, 137:2128-2133.

66. Newton ER, Piper JM, Shain RN, Perdue ST, Peairs W: Predictors of the vaginal microflora. Am J Obstet Gynecol 2001, 184:845-53, discussion 853855 .

67. Doderlein A: Die Scheidensekretuntersuchungen. Zentralb/ Gynaekol 1894, 18:10-14.

68. Eschenbach DA, Davick PR, Williams BL, Klebanoff SJ, Young-Smith K, Critchlow CM, Holmes KK: Prevalence of hydrogen peroxide-producing Lactobacillus species in normal women and women with bacterial vaginosis. J Clin Microbiol 1989, 27:251-256.

69. Hillier SL, Krohn MA, Klebanoff SJ, Eschenbach DA: The relationship of hydrogen peroxide-producing lactobacilli to bacterial vaginosis and genital microflora in pregnant women. Obstet Gynecol 1992, 79:369-373.

70. Hillier SL, Krohn MA, Rabe LK, Klebanoff SJ, Eschenbach DA: The normal vaginal flora, $\mathrm{H}_{2} \mathrm{O}_{2}$-producing lactobacilli, and bacterial vaginosis in pregnant women. Clin Infect Dis 1993, 16(Suppl 4):S273-281.

71. Ferris MJ, Norori J, Zozaya-Hinchliffe M, Martin DH: Cultivationindependent analysis of changes in bacterial vaginosis flora following metronidazole treatment. J Clin Microbiol 2007, 45:1016-1018.

72. Jakobsson T, Forsum U: Lactobacillus iners: a marker of changes in the vaginal flora? J Clin Microbiol 2007, 45:3145

73. Sobel JD: Bacterial vaginosis. Annu Rev Med 2000, 51:349-356.

74. Menard JP, Fenollar F, Henry M, Bretelle F, Raoult D: Molecular quantification of Gardnerella vaginalis and Atopobium vaginae loads to predict bacterial vaginosis. Clin Infect Dis 2008, 47:33-43.

75. Rodriguez Jovita M, Collins MD, Sjoden B, Falsen E: Characterization of a novel Atopobium isolate from the human vagina: description of Atopobium vaginae sp. nov. Int J Syst Bacteriol 1999, 49(Pt 4):1573-1576.

76. Bradshaw CS, Tabrizi SN, Fairley CK, Morton AN, Rudland E, Garland SM: The association of Atopobium vaginae and Gardnerella vaginalis with bacterial vaginosis and recurrence after oral metronidazole therapy. J Infect Dis 2006, 194:828-836.

77. Tamrakar R, Yamada T, Furuta I, Cho K, Morikawa M, Yamada H, Sakuragi N, Minakami $\mathrm{H}$ : Association between Lactobacillus species and bacterial vaginosis-related bacteria, and bacterial vaginosis scores in pregnant Japanese women. BMC Infect Dis 2007, 7:128.

78. Nyirjesy P, McIntosh MJ, Steinmetz Jl, Schumacher RJ, Joffrion JL: The effects of intravaginal clindamycin and metronidazole therapy on vaginal mobiluncus morphotypes in patients with bacterial vaginosis. Sex Transm Dis 2007, 34:197-202.

79. Zozaya-Hinchliffe M, Martin DH, Ferris MJ: Prevalence and abundance of uncultivated Megasphaera-like bacteria in the human vaginal environment. Appl Environ Microbiol 2008, 74:1656-1659.

80. Pybus V, Onderdonk AB: Evidence for a commensal, symbiotic relationship between Gardnerella vaginalis and Prevotella bivia involving ammonia: potential significance for bacterial vaginosis. J Infect Dis 1997, 175:406-413.

81. Amsel R, Totten PA, Spiegel CA, Chen KC, Eschenbach D, Holmes KK: Nonspecific vaginitis. Diagnostic criteria and microbial and epidemiologic associations. Am J Med 1983, 74:14-22.

82. Nugent RP, Krohn MA, Hillier SL: Reliability of diagnosing bacterial vaginosis is improved by a standardized method of gram stain interpretation. J Clin Microbiol 1991, 29:297-301.

83. Kim TK, Thomas SM, Ho M, Sharma S, Reich Cl, Frank JA, Yeater KM, Biggs DR, Nakamura N, Stumpf R, Leigh SR, Tapping RI, Blanke SR, Slauch JM, Gaskins HR, Weisbaum JS, Olsen GJ, Hoyer LL, Wilson BA: Heterogeneity of vaginal microbial communities within individuals. J Clin Microbiol 2009, 47:1181-1189.

84. Margulies $M$, Egholm M, Altman WE, Attiya S, Bader JS, Bemben LA, Berka J, Braverman MS, Chen YJ, Chen Z, Dewell SB, Du L, Fierro JM, Gomes XV, Godwin BC, He W, Helgesen S, Ho CH, Irzyk GP, Jando SC, Alenquer ML, Jarvie TP, Jirage KB, Kim JB, Knight JR, Lanza JR, Leamon JH, Lefkowitz SM, Lei M, Li J, Lohman KL, Lu H, Makhijani VB, McDade KE, McKenna MP, Myers EW, Nickerson E, Nobile JR, Plant R, Puc BP, Ronan MT, Roth GT, Sarkis GJ, Simons JF, Simpson JW, Srinivasan M, Tartaro KR, Tomasz A, Vogt KA, Volkmer GA, Wang SH, Wang Y, Weiner MP, Yu P, Begley RF, Rothberg JM: Genome sequencing in microfabricated high-density picolitre reactors. Nature 2005, 437:376-380. 
85. Parameswaran P, Jalili R, Tao L, Shokralla S, Gharizadeh B, Ronaghi M, Fire AZ: A pyrosequencing-tailored nucleotide barcode design unveils opportunities for large-scale sample multiplexing. Nucleic Acids Res 2007, 35:e130.

86. Sogin ML, Morrison HG, Huber JA, Mark Welch D, Huse SM, Neal PR, Arrieta JM, Herndl GJ: Microbial diversity in the deep sea and the underexplored "rare biosphere". Proc Natl Acad Sci USA 2006, 103:12115-11220.

87. Schloss PD, Westcott SL, Ryabin T, Hall JR, Hartmann M, Hollister EB, Lesniewski RA, Oakley BB, Parks DH, Robinson CJ, Sahl JW, Stres B, Thallinger GG, Van Horn DJ, Weber CF: Introducing mothur: open-source, platform-independent, community-supported software for describing and comparing microbial communities. Appl Environ Microbiol 2009, 75:7537-7541.

88. Wang Q, Garrity GM, Tiedje JM, Cole JR: Naive Bayesian classifier for rapid assignment of rRNA sequences into the new bacterial taxonomy. Appl Environ Microbiol 2007, 73:5261-5267.

89. Lozupone C, Hamady M, Knight R: UniFrac-an online tool for comparing microbial community diversity in a phylogenetic context. BMC Bioinformatics 2006, 7:371.

doi:10.1186/1471-2164-11-488

Cite this article as: Ling et al:: Molecular analysis of the diversity of vaginal microbiota associated with bacterial vaginosis. BMC Genomics 2010 11:488.

\section{Submit your next manuscript to BioMed Central and take full advantage of:}

- Convenient online submission

- Thorough peer review

- No space constraints or color figure charges

- Immediate publication on acceptance

- Inclusion in PubMed, CAS, Scopus and Google Scholar

- Research which is freely available for redistribution

Submit your manuscript at www.biomedcentral.com/submit 